\title{
Determinación de sulfuros en cementos por potenciometría con un electrodo selectivo de sulfuros
}

\author{
Determination of sulphides in cements by using \\ potentiometry with a selective electrode \\ of sulphides
}

\begin{abstract}
JOSE LUIS BERNAL, M. ${ }^{a}$ JESUS DEL NOZAL, LUIS DEBAN, M. ${ }^{a}$ LUZ TASCON, Drs. en Ciencias Quimicas y ANGEL SANCHEZ CERRATO, Lcdo. en Ciencias Químicas Departamento de Química Analítica de la Facultad de Ciencias. Universidad de Valladolid, España
\end{abstract}

\section{RESUMEN}

Se propone un método para la determinación de sulfuros, basado en el ataque con $\mathrm{HCl}(1$ : 3), destilación y posterior medida potenciométrica con un electrodo selectivo de sulfuros.

\section{SUMMARY}

A procedure for the determination of sulphides attackable by $\mathrm{HCl}(1: 3)$ in cements by means of a potentiometric determination with a selective electrodo of sulphides. is proposed.

\section{INTRODUCCION}

La presencia de sulfuros en el hormigón puede ser atribuida principalmente a dos orígenes: proveniente del cemento o debido a la composición de los áridos. En ambos casos, su contenido no debe sobrepasar un límite máximo tolerable, que depende lógicamente de la posterior utilidad que se vaya a dar al material, o bien del tipo de producto que se desea obtener.

Distintas Normas Internacionales señalan los límites máximos de contenido en azufre como sulfuro. Por ello la determinación de este elemento en materiales de edificación es de vital interés en la industria de la construcción. Sin embargo, la determinación de tal elemento presenta una apreciable dificultadad debido a sus características químicas: elevada basicidad e inestabilidad al aire.

En este trabajo proponemos un procedimiento para la determinación de sulfuros en cementos, basado en dos etapas: primero destilación del sulfuro, y segundo, determinación del mismo en el líquido de

\section{INTRODUCTION}

The presence of sulphides in concrete can mainly be attributed to two origins: coming from the cement itself or because of the arid composition. In both cases, its content can not exceed a tolerable maximum limit, which logically depends either upon the posterior use of the material or upon the type of product that we want to obtain.

Different International Rules establish the maximum limits of content of sulphur as sulphide. Therefore the determination of this element in building materials is of vital interest to the building industry. Nevertheless, the determination of such element presents an appreciable difficulty caused by its chemical characteristics; namely high basicity and inestability when exposed to the air.

In this paper we propose a procedure for the determination of sulphides in cements, performed in two stages; first the distillation of the sulphide and secondly its determination in the liquid of distillation using a selective 
destilado mediante el empleo de un electrodo selectivo de membrana sólida compuesta por cristales de sulfuro de plata.

La utilización de electrodos selectivos de iones, en la determinación de sulfuros, es muy variada como se deduce de los trabajos publicados al respecto; no obstante es escasa la bibliografía con respecto al tema que tratamos; de los consultados, los que presentan una mayor relación son los referentes a la determinación de sulfuros en cal (1), suelos y sedimentos fluviales (2-5).

Para realizar este estudio, se ha procedido a la determinación de sulfuros en distintas muestras patrón de cemento, mediante potenciometría con un electrodo selectivo de sulfuro, previo estudio de las condiciones idóneas de medida para la utilización del mismo.

\section{MATERIAL}

\section{Equipo}

- "Ion-activímetro" digital PHILIPS, modelo PW9414.

- Electrodo de referencia de doble unión de calomelanos saturado, PHILIPS, modelo $\mathrm{R} 44 / 2-\mathrm{SD} / 1$.

- Electrodo selectivo de sulfuro y plata PHILIPS IS-550-Ag.

- Equipo de destilación.

\section{Disoluciones}

\section{Disolución de sulfuro}

Se preparó disolviendo 24,0182 g de $\mathrm{Na}_{2} \mathrm{~S} .9 \mathrm{H}_{2} \mathrm{O}$ en agua desionizada y enrasando a un litro. Se valoró por retroceso añadiendo un exceso de $\mathrm{AgNO}_{3}$ y valorando éste potenciométricamente con $\mathrm{NaCl}$, utilizando el electrodo selectivo como indicador. La disolución de sulfuro se prepara momentos antes de su utilización, añadiéndose ácido ascórbico $(10 \mathrm{~g} / \mathrm{l})$ para prevenir la oxidación del sulfuro.

\section{Disolución de $\mathrm{AgNO}_{3}$}

Fue preparada disolviendo $16,9875 \mathrm{~g}$ de $\mathrm{AgNO}_{3}$ en agua desionizada y enrasando a un litro. Fue valorada frente a una disolución de $\mathrm{NaCl}$.

\section{Disolución de $\mathrm{NaCl}$}

Fue preparada disolviendo $5,8440 \mathrm{~g}$ de $\mathrm{NaCl}$, electrode of solid membrane made up of crystals of sulphide of silver.

The use of ion-selective electrode in the determination of sulphides is very varied as it can be deducted from the published literature; however, the bibliography respecting the matter of this paper is spare; from the literature that have been consulted, that with a major relationship are the one referred the determination of sulphides in lime (1), soils and river sediments (2-5).

In order to carry out this study, we have proceeded to the determination of sulphides in different standard samples of cements by using potentiometry with a selective electrode of sulphides, having previously studied the ideal conditions of measurement for its use.

\section{MATERIAL}

\section{Apparatus}

- Digital ion-activity meter PHILIPS PW9414.

- Reference electrode with double junction saturated calomel PHILIPS R44/2-SD/1.

- Selective electrode of sulphide and silver PHILIPS IS-550-Ag.

- Distillation equipment.

\section{Solutions}

Sulphide solution

It was prepared dissolving $24.0182 \mathrm{~g}$ of $\mathrm{Na}_{2} \mathrm{~S} .9 \mathrm{H}_{2} \mathrm{O}$ in de-ionised water and making level to a litre. It was valued by retrocession adding an excess of $\mathrm{AgNO}_{3}$ and valuing this by potentiometry with $\mathrm{NaCl}$, using the selective electrode as indicator. The sulphide solution is prepared just right before its use, adding ascorbic acid $(10 \mathrm{~g} / \mathrm{l})$ to prevent the oxidation of the sulphide.

$\mathrm{AgNO}_{3}$ solution

It was prepared dissolving $16.9875 \mathrm{~g}$ of $\mathrm{AgNO}_{3}$ in de-ionised water and making level to a litre. It was valued against a solution of $\mathrm{NaCl}$.

$\mathrm{NaCl}$ solution

It was prepared dissolving $5.8440 \mathrm{~g}$ of $\mathrm{NaCl}$, 
previamente desecado, en agua desionizada y enrasando a un litro.

Disolución de TISAB (Total lonic Strength Adjustment Buffer) para medir sulfuro

Está constituida por una mezcla de $\mathrm{KNO}_{3} 2 \mathrm{M}$

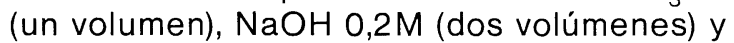
ácido ascórbico en una proporción de $10 \mathrm{~g} / \mathrm{l}$.

\section{EXPERIMENTAL}

\section{Destilación}

\section{Montaje}

La figura 1 muestra el esquema del montaje de destilación y absorción de $\mathrm{SH}_{2}$. previously dried up in de-ionised water and levelling off to a litre.

TISAB solution (Total Ionic Strength Adjustment Buffer) for sulphide measurement

It is constituted by a mixture of $\mathrm{KNO}_{3} 2 \mathrm{M}$ (a volume), $\mathrm{NaOH} \mathrm{0,2} \mathrm{M}$ (two volumes) and ascorbic acid in a $10 \mathrm{~g} / \mathrm{l}$.

\section{EXPERIMENTAL}

\section{Distillation}

Setting-up

Fig. 1 shows the scheme of the distillation and absorption setting up of $\mathrm{SH}_{2}$.

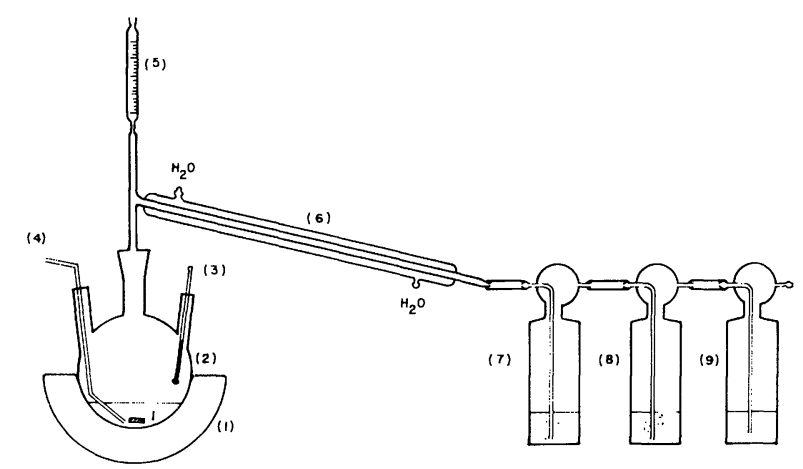

Fig. 1.-Destilación y absorción de $\mathrm{SH}_{2}$.

Fig. 1.-Distillation and absorption of $\mathrm{SH}_{\text {, }}$

Está constituido por una manta calefactora con agitación magnética (1), de temperatura regulable y el correspondiente agitador (I). Un matraz de destilación de tres bocas (2): en una de ellas se sitúa el termómetro (3), por otra se introduce un pasador de nitrógeno (4) y la boca central va conectada al refrigerante (6), el cual presenta una comunicación en su parte superior con la bureta (5) desde la que se deja caer $\mathrm{HCl}$. Los recipientes (7) y (8) contienen $25 \mathrm{ml}$ cada uno de disolución TISAB absorbente del $\mathrm{SH}_{2}$, y el recipiente (9) contiene una disolución de cadmio que permite observar si hay pérdidas de $\mathrm{SH}_{2}$ a la salida del recipiente (8), ya que de haberlas se forma un precipitado amarillo de fácil detección visual.

\section{Procedimiento}

Se pesan aproximadamente $5 \mathrm{~g}$ de muestra, previamente desecada a $105^{\circ} \mathrm{C}$, se introduce en el matraz de destilación y se añaden $75 \mathrm{ml}$ de agua desionizada; a continuación se adicionan lentamente desde la bureta $25 \mathrm{ml}$ de
It is constituted by a heating set with a magnetic stirring (1), regulable temperature and the corresponding agitator. A distillation matrass with three mouths (2); one is for the termometer setting (3), another one where the nitrogen is introduced through (4) and the central one that is connected to the refrigerant (6) which presents in the top a communication with the burette (5) from where we leave the clorhidric acid drop. Recipients (7) and (8) contain $25 \mathrm{ml}$ each of TISAB solution, which absorbs the $\mathrm{SH}_{2}$ and recipient (9) contains a cadmium solution which allows us to observe if there are loses of $\mathrm{SH}_{2}$ at the outgoing of the recipient (8). A yellow precipitate that is easily visually detected is formed in case of some lost.

\section{Procedure}

We take approximately $5 \mathrm{~g}$ of the sample, previously dried up at $105^{\circ} \mathrm{C}$; it is introduced into the distillation matrass and we add $75 \mathrm{ml}$ of de-ionised water; righ after that we add slowly from the burette $25 \mathrm{ml}$ of concentrated 
$\mathrm{HCl}$ concentrado, se conecta la manta calefactora y el pasador de nitrógeno. Se mantiene la destilación durante un tiempo no inferior a 25 minutos. Una vez determinada la misma, se recoge el líquido destilado sobre la disolución de TISAB y se lleva a un matraz enrasando a $100,0 \mathrm{ml}$, procediendo a su determinación.

\section{Estudio del Electrodo}

Se ha realizado un estudio sistemático de las características y funcionamiento del electrodo selectivo de sulfuro, en base a los parámetros operacionales que podian influir en las medidas: tiempo de medida, fuerza iónica y $\mathrm{pH}$, llegándose a las siguientes conclusiones:

- El tiempo para efectuar la medida debe ser de siete minutos, midiéndose las disoluciones, en el caso de línea de calibrado, en orden creciente de concentración.

- La fuerza iónica deberá mantenerse entre $0,4 \mathrm{M}$ y $1,3 \mathrm{M}$

- El pH del medio no deberá ser inferior a 13,0:

Estos dos últimos parámetros quedan totalmente regulados dentro de los límites óptimos de medida, al añadir a la disolución a analizar disolución TISAB, en la proporción de volumen que se indica en el trabajo.

En cuanto a la agitación, ésta se mantiene constante mediante un agitador magnético de velocidad regulable, debiendo ser la adecuada para que no se originen burbujas en la superficie de la membrana. La temperatura de trabajo es la ambiental.

La línea de calibrado, potencial (mV) - log concentración, presenta una vez fijados todos los parámetros una pendiente del orden de $30 \mathrm{mV}$ entre $10^{-1} \mathrm{M}$ y $5,2 \cdot 10^{-6} \mathrm{M}$, en concentración de sulfuro.

\section{Determinación Potenciométrica}

\section{Determinación directa}

Sobre $50 \mathrm{ml}$ de disolución TISAB, se destila el sulfuro de la muestra y se enrasa con agua desionizada hasta 100,0 ml. La disolución resultante se vierte en un vaso de $250 \mathrm{ml}$, se introducen los electrodos de referencia y selectivo, y se mide el potencial al cabo de siete minutos a temperatura y agitación constante. clorhidric acid and we connect the heating set and the nitrogen. Once the distillation is finished, the distillation liquid collected over the TISAB solution and it is taken to a matrass making level to $100 \mathrm{ml}$.

\section{Study of the electrode}

A systematic study of the characteristics and functioning of the selective electrode of sulphide has been done, based on the operational parameters that might influence the measurements: measurement time, ionic strength and $\mathrm{pH}$.

- The time of measurement must be of seven minutes, measuring the solutions successively in growing concentrations, and that must be done, in case of calibration line.

- The ionic strength must be kept between $0.4 \mathrm{M}$ and $1.3 \mathrm{M}$.

- The $\mathrm{pH}$ of the medium must be lower than 13.0

The two last parameters remain completely regulated between the optimum limits of measurement with the addition of TISAB solution in the volume proportion already indicated, to the sulution than must be analysed.

With respect to the stirring, this is kept constant using a magnetic agitator of regulable speed, that must be the adequate one so that bubbles are not produced in the surface of the membrane. The temperature during the job is the usual in laboratory.

The calibration line, potential ( $m V)$-log concentration, presents once all parameters are fixed, a slope of about $30 \mathrm{mV}$ between $10^{-1} \mathrm{M}$ and $5.2 \cdot 10^{-6} \mathrm{M}$ concentration of sulphide.

\section{Potentiometric Determination}

Direct determinaton

Over $50 \mathrm{ml}$ of TISAB solution, the sample of sulphide is distillated and level is made with de-ionised water to $100 \mathrm{ml}$. The resultant solution is poured in a beaker of $250 \mathrm{ml}$, the selective and reference electrodes are introduced and we measure the potential right after seven minutes with continous stirring and constant temperature. 
La concentración de sulfuro, se determina por comparación con la línea de calibrado preparada a partir de la disolución patrón de sulfuro.

Procedimiento recomendado. Método de adiciones patrón

Sobre $50 \mathrm{ml}$ de disolución TISAB, se destila el sulfuro de la muestra y se enrasa con agua desionizada hasta $100 \mathrm{ml}$. La disolución resultante se vierte en un vaso de $250 \mathrm{ml}$ y se introducen los electrodos selectivo y de referencia. A continuación sobre esta disolución se hacen sucesivas adiciones de $1 \mathrm{ml}$ de disolución de sulfuro de concentración conocida, $10^{-3} \mathrm{M}$, tomando las sucesivas medidas del potencial al cabo de siete minutos a temperatura y agitación constante. Una vez efectuados los cálculos correspondientes, se efectúa la representación gráfica y, por extrapolación del tramo recto obtenido, se calcula el volumen equivalente y a partir de él la concentración de sulfuro en la muestra.

En todos los casos al efectuar los cálculos debe tenerse en cuenta la dilución efectuada con respecto a la muestra original.

\section{RESULTADOS Y DISCUSIONES}

\section{Determinación directa}

Uno de los problemas que se plantea en la determinación de sulfuros en el cemento es. normalmente, su baja concentración y por lo tanto la obtención de valores que se alejan del intervalo óptimo de medida del electrodo. con el consiguiente aumento del error en los resultados, ya que la relación existente entre el error relativo cometido en la concentración y el error absoluto en el potencial, se obtiene a partir de la ecuacción correspondiente a la linea de calibrado, la cual responde a una expresión del tipo: $E=K-p \log C(1)$ donde $E$ representa el potencial en mili voltios. $\mathrm{K}$ es un valor constante, $\mathrm{p}$ es la pendiente de la línea de calibrado y $C$ la concentración en este caso del sulfuro.

La expresión (1) se puede transformar en:

$E=K-(p / 2,303) \operatorname{Ln} C ;$ por lo tanto $d E=(p / 2,303) \cdot d C / C$ y pasando a incrementos finitos $\triangle E=(p / 2,303) \cdot \triangle C / C$, pero como $(\triangle \mathrm{C} / \mathrm{C}) \cdot 100=\varepsilon \% ; \varepsilon \%=\triangle E$ $(230,3 / p)$. De esta última expresión se deduce fácilmente que el $\varepsilon \%$ aumenta a medida que lo hace $\triangle E$, lo cual ocurre siempre de forma progresiva cuando nos alejamos de los límites nernstianos de medida.
The concentration of sulphide is determined by comparison with the calibration line prepared from the standard solution of sulphide.

Recommended procedure. Standard additions method

Over $50 \mathrm{ml}$ of TISAB solution, the sulphide of the sample is distillated and it is levelled off with de-ionised water to $100 \mathrm{ml}$. The resultant solution is then poured into a $250 \mathrm{ml}$ beaker and the reference and selective electrodes are introduced. Afterwards, successive additions of a millilitre of sulphide of a known concentration $\left(10^{-3} \mathrm{M}\right)$ are made over that solution. Having maintained constant the stirring and the temperature, we measure the potential seven minutes after each addition. Once the corresponding calculations have been made, we draw a representative graph and by extrapolation of the straight portion obtained we calculate the equivalent volume and from it, the sulphide concentration in the sample.

The dilution made from the original sample must be taken into account when the calculations are made in any case.

\section{RESULTS AND DISCUSSION}

Direct determination

One of the problems that the determination of sulphides in the cement is usually posed by its low concentration. In consequence, we obtain values that are far from the optimum interval of electrode measurement with the subsequent increase in the error of the results, because the relation between the relative error that is made in the concentration and the absolute error in the potential is obtained from the equation that corresponds to the calibration line, which responds to a expression of the type: $E=K-p \log C$ (1) where $E$ represents the potential in millivolts, $K$ is a constant value, $p$ is the slope of the calibration line and $C$ is the sulphide concentration in the present case.

\section{Expression (1) can be tranformed into:}

$E=K-(p / 2.303) \operatorname{Ln} C$; hence $d E=(p / 2.303) \cdot d C / C$ and expressing it as finite increments $\triangle E=(p / 2.303) \cdot \triangle C / C$, but as $(\triangle C / C) \cdot 100=\varepsilon \% ; \varepsilon \%=\triangle E(230.3 / p)$. From the last expression it can easily be deducted that $\varepsilon \%$ increases according to the $\triangle E$, which always happens in a progressive way when we go farther from the nerstian limit of the measurements. 
De los resultados obtenidos para distintas muestras patrón de cemento (Tabla I), se deduce que los errores experimentales cometidos al aplicar la técnica de potenciometría directa, alcanzan en algunos casos valores superiores al $75 \%$.
From the obtained results for the different standard samples of cements (Table I), we deducte that the experimental errors which are made when the direct potentiometry technique is applied reach, in some of the cases, values that are superior to $75 \%$.

$T_{A B L A}\left(T_{A B L E}\right) \quad$ ।

\begin{tabular}{|c|c|c|}
\hline $\begin{array}{c}\mathbf{S}^{-} \text {muestra }(\mu \mathbf{g}) \\
\mathbf{S}^{-} \text {sample }(\mu \mathbf{g})\end{array}$ & $\begin{array}{c}\mathbf{S}^{-} \text {encontrado }(\mu \mathbf{g}) \\
\mathbf{S}^{*} \text { found }(\mu \mathbf{g})\end{array}$ & Error \% \\
\hline 20,3 & 4,6 & 77,3 \\
40,0 & 26,2 & 34,5 \\
60,2 & 42,7 & 29,1 \\
80,6 & 59,1 & 26,7 \\
100,2 & 83,0 & 17,2 \\
150,1 & 134,3 & 10,5 \\
200,0 & 183,8 & 8,1 \\
250,4 & 232,7 & 7,1 \\
500,3 & 474,6 & 5,1 \\
$1.000,0$ & 947,2 & 5,3 \\
\hline
\end{tabular}

Estudio del metodo de adiciones

Debido a los problemas ya citados que se plantean en la determinación por potenciometría directa, se pensó en la posibilidad de aplicar el método de adiciones patrón.

Supongamos $\mathrm{C}_{1}$ la concentración de sulfuro en la disolución inicial de volumen $\mathrm{V}_{1}$, se cumplirá que: $E_{1}=K-p \log C_{1}(2)$; después de añadir un volumen $V_{2}$ de una disolución patrón de sulfuro de concentración $\mathrm{C}_{2}$, tendremos que:
Study of the additions method

Due to the problems already described that are posed in the determination for direct potentiometry, the possibility of the standard additions method application was thought.

Let $C$ the concentration of sulphide in the initial solution of $V$, volume; It should be that: $E_{1}=K-p \log C_{1}(2)$; after having added a $V_{2}$ volume of a standard solution of sulphide of $C_{2}$ concentration, we get:

$$
E_{2}=K-p \log \frac{C_{1} V_{1}+C_{2} V_{2}}{V_{1}+V_{2}}
$$

Restando las expresiones (3) y (2) obtendremos:

$$
\Delta E=E_{2}-E_{1}=-p \log \frac{C_{1} V_{1}+C_{2} V_{2}}{V_{1}+V_{2}} \cdot \frac{1}{C_{1}}
$$

o bien

$$
10^{-\therefore E / p}\left(V_{1}+V_{2}\right) \cdot C_{1}=C_{1} V_{1}+C_{2} V_{2}
$$


Si se dividen los dos miembros de esta última ecuación por $\mathrm{C}_{1} \mathrm{~V}_{1}$ se obtiene la ecuación:
If we divide the two members of the last equation by $C_{1} V_{1}$ the equation obtained is the following:

$$
10^{-\Delta E / p}\left(\frac{V_{1}+V_{2}}{V_{1}}\right)=1+\frac{C_{2} V_{2}}{C_{1} V_{1}}
$$

que corresponde a la ecuación de una recta. Cuando el primer término de la expresión (5) sea igual a cero también lo será el segundo término, con lo cual tendremos que: $C_{1}=-C_{2}\left(V_{2} / V_{1}\right)$. En este caso, $V_{2}$ corresponde al valor negativo, en el que la extrapolación a cero del tramo recto corta al eje de abscisas. which corresponds to a straight line equation. When the first term of expression (5) is equal to zero, the second term will be too. So, we get: $C_{1}=-C_{2}\left(V_{2} / V_{1}\right)$. In this case $V_{2}$ is the negative value in which the extrapolation to zero of the straight portion cuts the abscisas axis.

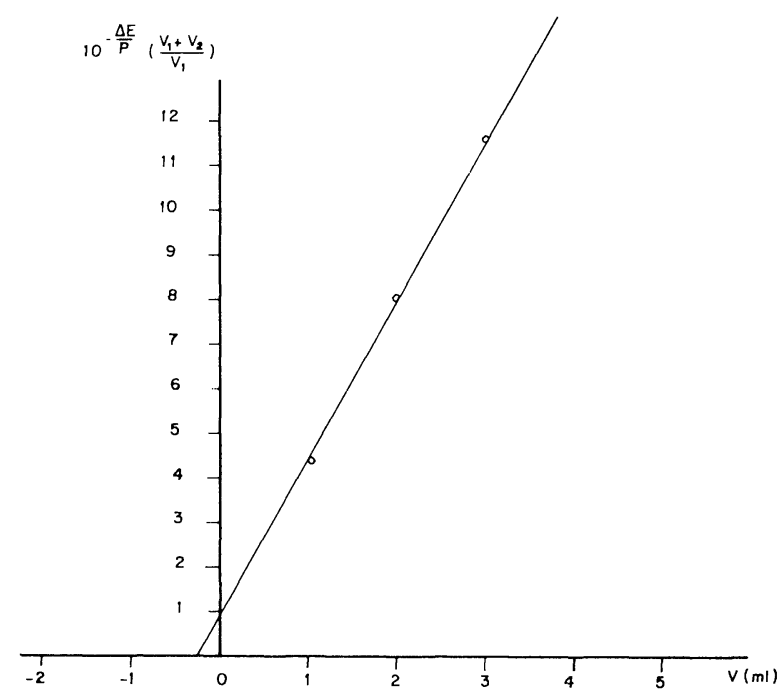

Fig. 2.-Aplicación del método de adiciones.

Fig. 2.-Application of the additions method.

Tabla (TABLE) II

\begin{tabular}{|c|c|c|}
\hline $\begin{array}{c}\text { S muestra }(\mu \mathbf{g}) \\
\text { S sample }(\mu \mathbf{g})\end{array}$ & $\begin{array}{c}\text { S encontrado }(\mu \mathrm{g}) \\
\mathbf{S} \text { found }(\mu \mathbf{g})\end{array}$ & Error \% \\
\hline 20,3 & 17,1 & 15,8 \\
40,6 & 36,4 & 10,3 \\
60,2 & 56,7 & 5,8 \\
80,6 & 76,1 & 5,6 \\
100,2 & 95,2 & 5,0 \\
150,1 & 142,1 & 5,3 \\
200,0 & 189,5 & 5,3 \\
250,4 & 237,9 & 5,0 \\
500,3 & 476,3 & 4,8 \\
$1.000,0$ & 951,4 & 4,9 \\
\hline
\end{tabular}

En la fig. 2 se representa, gráficamente, la aplicación del método a una de las muestras
In figure 2 the application of the method to one of the standard samples of cement, the 
patrón de cemento, la correspondiente a un contenido de 100,2 $\mu \mathrm{g}$. Los resultados obtenidos para todas las muestras, con respecto a su contenido en sulfuro, se refleja en la Tabla II y, como puede deducirse de los mismos, las cantidades determinadas al aplicar el método de adiciones y las existentes, no difieren en cuanto al valor relativo en un porcentaje superior al $6 \%$ cuando el sulfuro de la muestra es superior a $60 \mu \mathrm{g}$, mejorándose por lo tanto muy apreciablemente los resultados con respecto a los obtenidos por potenciometría directa. one with $100.2 \mu \mathrm{g}$ content, is represented. The results obtained for all samples regarding its sulphide content are displaid in Table II and as it can be deducted from it, the determinated quantities when the additions method is applied and the existing ones, do not differ, considering the relative value, in percentage superior to $6 \%$ provided that the sulphide in the sample is higher than $60 \mu \mathrm{g}$, improving subsequently in a appreciable way the results when compared to those obtained by direct potentiometry.

\section{BIBLIOGRAFIA}

(1) MELLON, E. F. and GRUBER, H. A.: Behavior of the solid state sulfide electrode in lime-sulfide solutions. J. Am. Leather Chem. Assoc., 65 (4), 1970, 154.

(2) ALLAM, A. I.; PITTS, G. and HOLLIS, J. P.: Sulfide determination in submerged soils with an lon-Selective Electrode. Soil Science, $114(6), 1972,456$.

(3) BARICA, J.: Use of a silver-sulfide electrode for standardizing aqueous sulfide solution in determining sulfide in water. J. Fisheries Res. Bd. Canada, 30 (10), 1973, 1589.

(4) GREEN, E. J. and SCHNITKER, D.: The direct titration of water-soluble sulfide, in Estuarine Muds of Montsweag Bay, Maine. Marine Chemistry, 2, 1974, 111.

(5) BAUMAN, E. W.: Determination of parts per billion sulfide in water with the sulfide-selective electrode. Anal. Chem., 46 (9), 1974, 1.345

\section{publicación del i.e.t.c.c.}

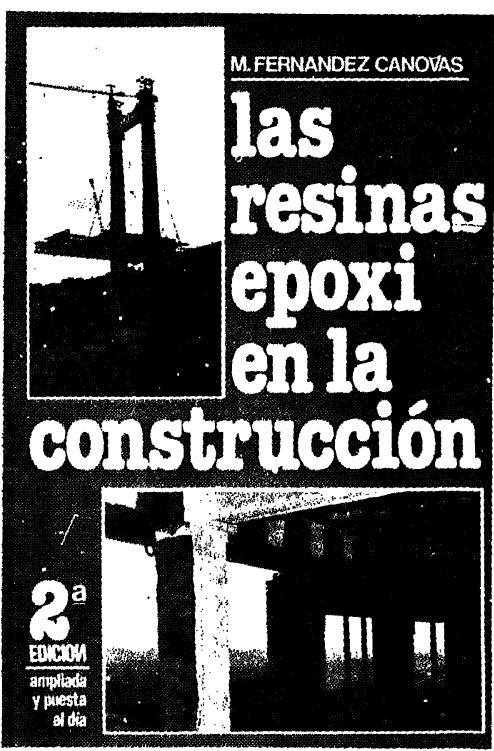

12
Manuel Fernández Cánovas Dr. Ingeniero de Construcción

Este libro, el primero en lengua castellana sobre resinas epoxi aplicadas a la construcción, está dirigido a arquitectos, ingenieros, constructores y aplicadores. En él, sobre una reducida base teórica imprescindible, se asienta toda una extensa gama de aplicaciones de gran interés.

El autor trabaja desde hace muchos años en el campo de la investigación, especialmente en el estudio de refuerzos y reparaciones estructurales realizados con resinas epoxi.

Con un lenguaje sencillo se tocan todos los problemas que pueden presentarse en la construcción y en los que la solución puede radicar en el correcto empleo de las resinas epoxi.

Se estudian los componentes de las formulaciones epoxi, sus propiedades fisicas y quimicas, y aplicaciones, detenièndose, detalladamente, en las siguientes:

Unión de hormigón fresco a hormigón endurecido. - Unión de hormigones entre si. -.. Inyecciones de fisuras grietas. . Unión de acero a hormigón. - Barnices y pinturas. - Las combinaciones brea-epoxi. - Revestimientos de depósitos alimenticios. - Sellado de superficies ceramicas. - Protección de tubos. - Los suelos epoxi en sus diferentes variantes. -- Terrazo epoxi. … Reparación de baches. - Reparación de desperfectos en estructuras. - Reparación de carreteras de hormigón... Juntas elásticas.--Guardacantos de tableros de puentes.-Refuerzos de pilares, vigas, forjados y zapatas, etc. - Consolidación de suelos.-Anclajes. - Protección de aceros en pretensado.

Se termina con unos capitulos dedicados a la limpieza y preparación de las superficies según los materiales a unir al control del estado superficial de éstos; a las condiciones de temperatura de aplicación; limpieza de los útiles de trabajo; precauciones en el manejo de los sistemas; almacenaje, mezcla y manejo de las formulaciones epoxi métodos de ensayo de sistemas y aplicaciones epoxidicas.

Un volumen encuadernado en cartoné plastificado con lomo de tela, de $17 \times 24 \mathrm{~cm}$, compuesto de 334 páginas y 158 figuras y fotografias.

Madrid, 1981.

Precios: España, 1.700 ptas.; extranjero, \$ USA 34.00 